triclopyr resulted in reduced kikuyugrass competition and increased plug growth in all turf cultivars (fig. 4).

Kikuyugrass density at the end of the experiment was reduced most by sequential treatments of MSMA plus triclopyr (7.3 stems $/ \mathrm{ft}^{2}$ compared with $203.5 \mathrm{stems} / \mathrm{ft}^{2}$ in the control plots).

Sequential treatments of MSMA and triclopyr reduced kikuyugrass density to 54.4 and 39.0 stems $/ \mathrm{ft}^{2}$, respectively.

\section{Management program}

The results of this research can be integrated into a kikuyugrass management program. Where cool-season species such as perennial ryegrass, tall fescue and Kentucky bluegrass are in a mixed sward with kikuyugrass, sequential applications of a combination of MSMA and triclopyr will reduce the density and competitiveness of the kikuyugrass, allowing the desired cool-season species to reestablish themselves. Some reseeding of the cool-season species may be necessary during the reestablishment process if the initial cool-season stand is not adequate or uniform. Once the desired species takes hold again, proper management to keep it competitive, including an occasional herbicide treatment as needed, should prevent kikuyugrass reinvasion.

The manufacturer of triclopyr has altered labeling information to include multiple applications of triclopyr and triclopyr plus MSMA for kikuyugrass control in cool-season turf.

D. W. Cudney, V. A. Gibeault and J.S. Reints are Extension Weed Specialist, Environmental Horticulture Specialist, and Staff Research Associate, respectively, in the Department of Botany and Plant Sciences, UC Riverside; J. A. Downer and J. $M$. Henry are Farm Advisors in Ventura and Orange counties, respectively. C. $L$. Elmore is Extension Weed Specialist, UC Davis.

This research and continuing research with kikuyugrass control involving additional herbicides and turf species is being supported by The Northern and Southern California Golf Associations.

\title{
Tomatoes respond to simple drip irrigation schedule and moderate nitrogen inputs
}

\author{
Timothy K. Hartz $\square$ Michelle LeStrange $\square$ Donald M. May
}

\begin{abstract}
Scheduling drip irrigation of fresh market tomatoes according to CIMIS ETo data and plant canopy development has proved simple and efficient. Using an easy calculation, maximum yields were produced in both a mild coastal climate and the San Joaquin Valley. In similar trials, researchers confirmed that drip-irrigated tomato crops need only modest levels of nitrogen fertigation and successfully tested a new, portable device that will enable growers to measure petiole nitrogen without leaving the farm.
\end{abstract}

The fresh market tomato industry in recent years has experienced a drip irrigation revolution. In the mid-1980s, less than $20 \%$ of California's acreage was drip irrigated; today, the majority of growers of fresh market tomatoes have made the switch. This rapid change has been driven in part by a concern over water availability, but mainly by the advances in drip irrigation technology, which have reduced costs (relative to other production inputs), improved system performance and manageability, and dramatically improved yields.

Now the challenge for fresh market tomato growers is to manage drip irrigation for high crop productivity while maximizing the efficiency of irrigation and nitrogen fertigation. Finding the most appropriate drip irrigation and nitrogen schedules was the goal of the studies we conducted from 1990 to 1992 at the UC South Coast Field Station (SCFS) in Irvine and the West Side Field Station (WSFS) near Five Points.

\section{Scheduling irrigation}

A 2-year trial at SCFS examined three methods of scheduling irrigation: Two treatments were based on estimates of evapotranspiration (the loss of water through evaporation from the soil surface and plant transpiration, abbreviated here as ETo) generated by the California Irrigation Management and Information System (CIMIS) computerized weather network. In one of them, ETo values were modified for crop growth stage by multiplying by predetermined crop coefficients (fig. 1) adapted from those in the UC Cooperative Extension Leaflet 21427, which were developed by compiling information from many tomato irrigation studies. In the other treatment, CIMIS ETo was modified for crop growth stage by multiplying by the estimated percentage of the soil surface covered by foliage; foliage cover was estimated by measuring the average plant canopy spread (in inches) and dividing by the bed width (60 inches).

The advantage of using a crop canopy coverage percentage instead of

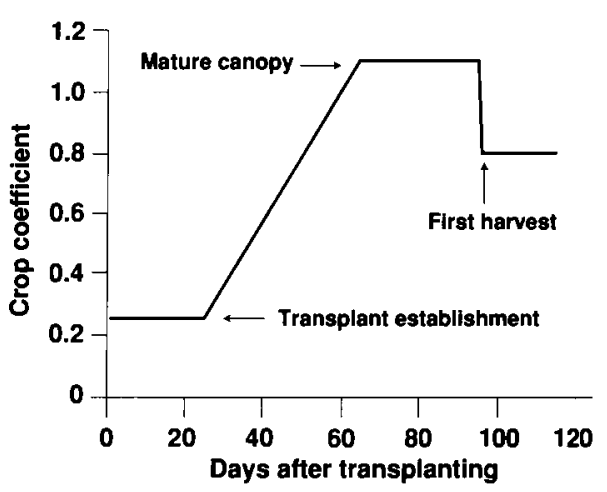

Fig. 1. UC Cooperative Extension crop coefficients used in the drip irrigation scheduling trial at SCFS. 


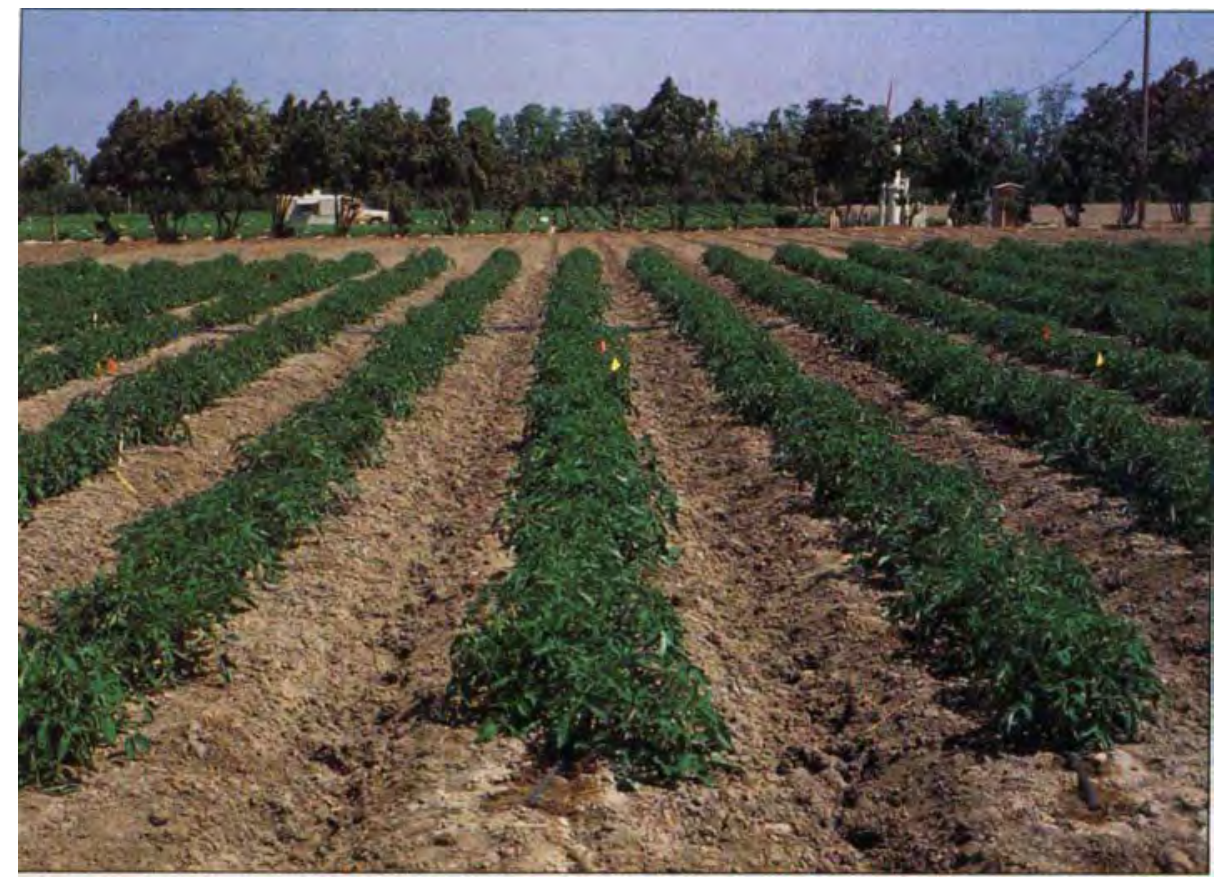

crop coefficients is that it more closely tracks the plant vigor of a particular field and is unaffected by field configuration. The published crop coefficients reflect "standard" field conditions and can require considerable modification for efficient use. The plants in both CIMIS ETo studies were irrigated either daily or three times per week.

The third approach was designed as a deficit irrigation treatment, replacing less water than the plants use, to impose a moderate level of water stress. The plants were irrigated only when $20 \%$ of available moisture was depleted, measured by tensiometers at a 12-inch depth. During canopy development, each application was 0.15 inch; once the crop canopy was fully developed, applications were increased as required to maintain available soil moisture at $80 \%$ of ETo. Irrigation frequency varied from every 4 to 7 days early in the season to daily $a^{+}$ the end of the season.

The trial plots were arranged in a randomized complete block design, with four 50-foot replications. The soil was San Emigdio sandy loam with $11 \%$ (1.3 inches $/ \mathrm{ft})$ available moisture capacity. A single drip irrigation tube was buried 6 inches deep in the center of each 60 -inch bed. A preplant application of $50 \mathrm{lb} \mathrm{N}$ and $60 \mathrm{lb} \mathrm{P}_{2} \mathrm{O}_{5} / \mathrm{ac}$ was supplemented by eight weekly applications of $15 \mathrm{lb} \mathrm{N/ac}$ applied in the irrigation water, for a seasonal total of $170 \mathrm{lb} \mathrm{N} / \mathrm{ac}$. Transplants of 'Bingo' tomato were set in the field on April 26 in 1990 and April 19 in 1991, and grown unmulched under bush (nontrellised) culture. After three weeks for transplant establishment, the different irrigation treatments were initiated. Tensiometers, installed in all plots at 12- and 18-inch depths, were read daily. Routine pest control practices were followed.

Breaker-stage fruit were harvested twice, followed by a final harvest of breaker and mature green fruit. Fruit were separated by size and condition according to USDA standards.

There was no significant difference in either year between the crop coeffi-
Drip-irrigated tomato plots at South Coast Field Station. Drip irrigation has become a standard practice for fresh market tomato production in California.

cients treatment and the percent canopy coverage treatment with respect to total or marketable yields (table 1), or fruit size distribution; all plots showed high yields and a high percentage of extra large fruits ( $>23 / 4$ inch diameter). Daily irrigation did not improve crop productivity compared with irrigation three times per week. The deficit irrigation treatment based on soil moisture depletion produced yields equivalent to the other treatments in 1991 and showed only a modest yield decline in 1990. In neither year was the incidence of blossom end rot or other water stress-related defects significant.

Tensiometer readings revealed that both the crop coefficients treatment and the percent canopy coverage treatment maintained soil moisture in the top 18 inches with minimal stress (readings ranged between 10 and 25 centibars), indicating that these scheduling approaches provided a reasonable estimation of actual evapotranspiration. The soil moisture depletion scheduling technique was indeed a deficit irrigation treatment, with tensiometer values rising to 45 centibars or higher by first harvest; yet this moderate stress resulted in only minor yield reductions. This study was conducted in the relatively mild coastal climate of Orange County, however; deficit irri-

\begin{tabular}{|c|c|c|c|c|c|}
\hline \multirow[b]{2}{*}{ Season } & \multirow[b]{2}{*}{$\begin{array}{l}\text { Irrigation } \\
\text { treatment }\end{array}$} & \multicolumn{2}{|c|}{ Fruit yield* } & \multicolumn{2}{|c|}{ Irrigation volume† } \\
\hline & & Total & Marketable & $\begin{array}{l}\text { Inches } \\
\text { applied }\end{array}$ & $\begin{array}{c}\text { \% Seasonal } \\
\text { ETo }\end{array}$ \\
\hline 1990 & $\begin{array}{l}\text { Crop coefficients } \\
\text { Canopy coverage } \\
\text { Soil moisture depletion }\end{array}$ & $\begin{array}{l}\text {....... ca } \\
4,330 \mathrm{a} \neq \\
4,520 \mathrm{a} \\
3,820 \mathrm{~b}\end{array}$ & $\begin{array}{r}\text { ns/ac }{ }^{*} \ldots \\
3,850 \mathrm{a} \\
3,980 \mathrm{a} \\
3,270 \mathrm{~b}\end{array}$ & $\begin{array}{l}13.6 \\
12.9 \\
10.4\end{array}$ & $\begin{array}{l}83 \\
79 \\
64\end{array}$ \\
\hline 1991 & $\begin{array}{l}\text { Crop coefficients } \\
\text { Canopy coverage } \\
\text { Soil moisture depletion }\end{array}$ & $\begin{array}{l}5,340 \\
4,780 \\
4,950 \\
\text { ns }\end{array}$ & $\begin{array}{l}4,810 \\
4,380 \\
4,770 \\
\text { ns } \S\end{array}$ & $\begin{array}{r}12.5 \\
11.4 \\
9.8\end{array}$ & $\begin{array}{l}89 \\
81 \\
70\end{array}$ \\
\hline
\end{tabular}

"25 lb net weight

tIrrigation from initiation of differential treatments through harvest. Seasonal ETo (same period) was 16.3 inches (1990) and 14.0 inches (1991).

$\mp$ Yields followed by the same letter are not significantly different at $\mathrm{P}=.05$

$\S$ Not significant at $\mathrm{P}=.05$ 


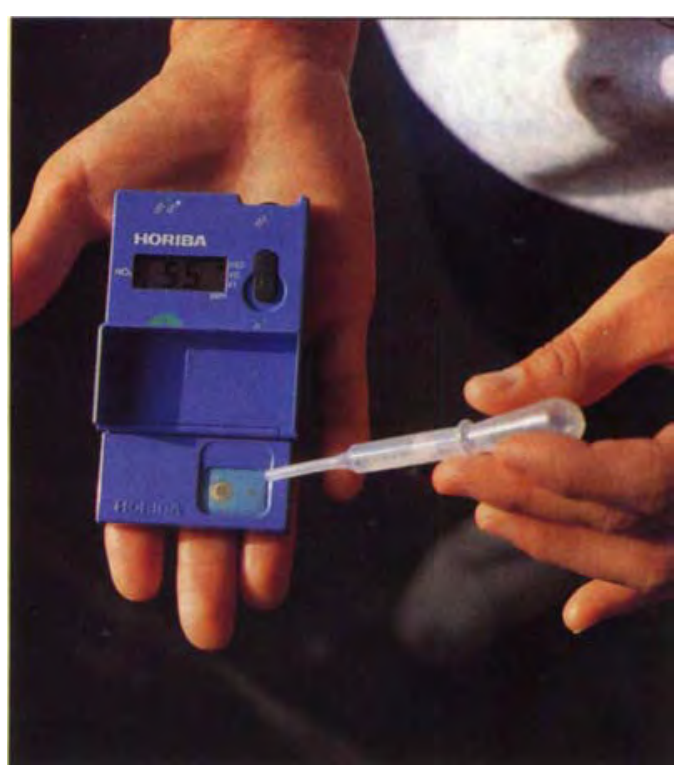

Analysis of petiole sap by nitrate-selective electrode can be a useful, on-farm nitrogen monitoring technique.

gating in more stressful environments may result in substantial yield losses.

Total water applied was similar in the crop coefficients treatment and the percent canopy coverage treatment and substantially less in the soil moisture depletion treatment (table 1). In this study, our prior knowledge of crop phenology at this site, and a row configuration that gave complete crop canopy coverage, allowed us to use the predetermined crop coefficients efficiently. Since these conditions will not always be met, the percent canopy coverage method may be a more efficient tool than the crop coefficients. The way we determined percent canopy coverage is simple and quick, easily adopted by commercial growers. Water application was modest in all treatments, averaging 67 to $86 \%$ of seasonal CIMIS ETo over the 2 seasons of our study.

\section{San Joaquin Valley trial}

We conducted a subsequent field trial in 1992 at WSFS to test the percent canopy cover method in the San Joaquin Valley. The field (Panoche clay loam) was worked into 66-inch beds with a single drip tape buried 8 inches deep. A preplant application of $120 \mathrm{lb} \mathrm{P}_{2} \mathrm{O}_{5} / \mathrm{ac}$ was augmented by eight weekly applications of $28 \mathrm{lb} \mathrm{N} /$ ac for a seasonal total of $225 \mathrm{lb} \mathrm{N} / \mathrm{ac}$. 'Keno' tomato transplants were planted April 2; three different irrigation treatments were initiated May 8. Experimental design was randomized complete block, with five 30 -foot-long replications.

Irrigation treatments were all calculated using CIMIS ETo multiplied by the percent crop canopy coverage, estimated as previously described, then multiplied by $0.9,1.1$ or 1.3 to determine the amount of irrigation for each of the three treatments. All treatments were irrigated three times per week. A single harvest of mature green fruit was taken on July 1 and evaluated by size and condition as previously described

There was no significant difference in tomato yield (table 2) or fruit size distribution among the three irrigation treatments. Tensiometer readings confirmed that the driest irrigation regime was a deficit irrigation treatment, but the stress did not compromise yield, undoubtedly due to the high waterholding capacity of this soil. Using the percent canopy coverage to estimate crop water demand was an efficient technique, allowing maximum crop productivity with a seasonal water application only 75 to $89 \%$ of seasonal CIMIS ETo.
Collectively, these studies clearly indicate that high yields of fresh market tomatoes can be achieved by scheduling drip irrigation on the basis of CIMIS ETo adjusted for crop growth stage by estimating percent canopy coverage. Barring salinity problems, which would require a significant in-season leaching fraction, irrigation in excess of this amount is unnecessary and may negatively impact yields.

\section{Assessing nitrogen rates}

A multitude of studies in California have examined nitrogen requirements of tomatoes, the general consensus being that 100 to $200 \mathrm{lb} \mathrm{N} / \mathrm{ac}$ is usually sufficient for maximum production. However, nearly all of these studies were done on furrow-irrigated plots, leaving some question whether nitrogen requirements for drip-irrigated tomatoes are different. Currently, the amount of nitrogen individual growers apply on their drip-irrigated tomatoes varies widely.

In 1992 we conducted a field trial at WSFS to determine drip-irrigated tomato plants' response to different levels of nitrogen fertigation. The field had been fallow for a year; residual inorganic nitrogen in the top 30 inches of soil was approximately $110 \mathrm{lb}$ N/ac, a moderate level compared with typical vegetable crop areas of the San Joaquin Valley.

The study was structured in the same way as the WSFS irrigation scheduling study, described earlier. Nitrogen in the form of urea ammonium nitrate fertilizer (UN-32) was applied in irrigation water in eight equal weekly increments at seasonal rates of $0,75,150,225$ and $300 \mathrm{lb} \mathrm{N} / \mathrm{ac}$. The
TABLE 2. Effect of irrigation regime based on canopy coverage on fresh market tomato yields and irrigation volume at WSFS, 1992

\begin{tabular}{|c|c|c|c|c|}
\hline \multirow[b]{2}{*}{ Irrigation regimeł } & \multicolumn{2}{|c|}{ Fruit yield } & \multicolumn{2}{|c|}{ Irrigation volume† } \\
\hline & Total & Marketable & Inches applied & $\%$ Seasonal ETo \\
\hline \multicolumn{5}{|c|}{........ cartons/ac ${ }^{*} \ldots . .}$. \\
\hline $90 \%$ & 4,810 & 3,420 & 11.5 & 75 \\
\hline $110 \%$ & 4,780 & 3,590 & 13.7 & 89 \\
\hline \multirow[t]{2}{*}{$130 \%$} & 4,170 & 3,160 & 15.9 & 103 \\
\hline & $\mathrm{ns \S}$ & ns & & \\
\hline
\end{tabular}

$25 \mathrm{lb}$ net weight

†Irrigation from initiation of treatments through harvest. Seasonal ETo (same period) was 15.4 inches.

$\ddagger$ CIMIS ETo $x$ percentage of canopy coverage $x$ stated percentage

$\S$ no significant difference
TABLE 3. Effect of nitrogen fertilization rate on fresh market tomato yields at WSFS, 1992

\begin{tabular}{ccc}
\hline \hline $\begin{array}{c}\text { Seasonal N rate } \\
\text { (Ib/ac) }\end{array}$ & \multicolumn{2}{c}{ Fruit yield } \\
\cline { 2 - 3 } & Total & Marketable \\
\hline & 3,640 & cartons/ac*........ \\
75 & 4,390 & 2,840 \\
150 & 4,480 & 3,360 \\
225 & 4,780 & 3,290 \\
300 & 4,160 & 3,590 \\
Significance† & $\mathrm{Q}$ & 3,088 \\
"25 lb net weight & & $\mathrm{Q}$ \\
†Linear (L) or quadratic (Q) significance at $\mathrm{p}=0.05$
\end{tabular}


plots were irrigated three times per week, with the application volume calculated as follows: CIMIS ETo $x$ percent canopy coverage $\times 1.1$. Leaching of nitrate beyond the root zone was therefore a minor concern, due to the small leaching fraction and relatively small individual water applications.

Total and marketable tomato yield showed a quadratic response to nitrogen fertigation, with only small differences in crop response"to nitrogen rates from 75 to $225 \mathrm{lb} / \mathrm{ac}$ (table 3). Excessive fertilizer $(300 \mathrm{lb} / \mathrm{ac})$ tended to depress fruit yield. Fruit size distribution was not affected by nitrogen rate. These results reinforce prior studies, which suggested that, in typical central California conditions, modest levels of nitrogen fertilization will maximize tomato productivity. Tomato plants develop a deep, aggressive root system that is highly efficient at extracting nitrogen from the soil. Tissue samples taken at early fruit set showed that the $\mathrm{NO}_{3}-\mathrm{N}$ concentration in dry petioles in all treatments was within the currently accepted sufficiency range; sampling 2 weeks preharvest revealed deficient petiole $\mathrm{NO}_{3}-\mathrm{N}$ in the 0 and $75 \mathrm{lb} \mathrm{N} /$ ac treatments.

\section{On-farm nitrogen test}

During the trial, we collected duplicate petiole samples to evaluate a new technique for determining crop nitrogen status quickly on the farm. With a portable, battery-operated, nitrate-selective electrode, we measured the $\mathrm{NO}_{3}-\mathrm{N}$ concentration of petiole sap, first crushing at least 15 petioles from different plants to get a representative sap sample We had two goals in mind: to define the numerical relationship between fresh sap and dry tissue $\mathrm{NO}_{3}-\mathrm{N}$ concentration, and to compare the accuracy of this technique with standard laboratory analysis of dry tissue.

Nitrate- $\mathrm{N}$ concentration of fresh sap in our petiole samples, as measured by the electrode, was highly correlated with $\mathrm{NO}_{3}-\mathrm{N}$ in dry tissue (fig. 2). Because of the high water content of petiole sap, its $\mathrm{NO}_{3}-\mathrm{N}$ concentration was numerically much lower than the dry tissue values. The relationship was not affected by crop growth stage, but it should be noted that all our petiole samples were taken from young, re- cently expanded leaves. Additional petiole sap samples, collected from other fields and other tomato varieties, showed the same relationship, indicating that site and variety have relatively little influence. This lack of site and variety effects was also found to be true of other vegetable crops such as lettuce and pepper. However, it should be noted that all fields sampled were adequately watered; a high degree of water stress may modify the relationship of fresh sap to dry tissue $\mathrm{NO}_{3}-\mathrm{N}$ concentration.

The nitrate-selective electrode is sensitive to temperature fluctuations, so we conducted all the analyses indoors in a temperature-controlled environment; to use the electrode technique efficiently on the farm, growers will need to collect samples from many different fields, and then return to a central location to process and analyze them However, held on ice in plastic bags, petiole samples can be stored for several hours before analysis.

The trial results showed that sap analysis by nitrate-selective electrode is somewhat less precise than conventional laboratory analysis of dry tissue. The most appropriate use of the new technique is for routine field monitoring in conjunction with periodic conventional tissue testing at a laboratory. The nitrate-selective electrode costs about $\$ 300$ and should last for hundreds of sap measurements.

\section{Conclusions}

CIMIS ETo estimates together with a visual estimate of the percent of the ground covered by foliage offer a simple and effective way to calculate

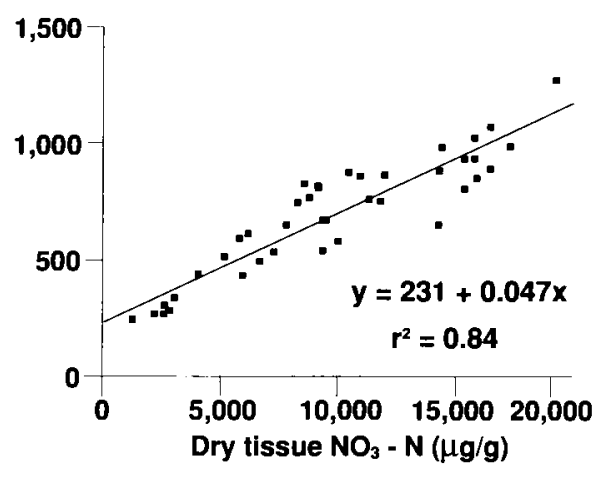

Fig. 2. There is a high correlation between $\mathrm{NO}_{3}-\mathrm{N}$ concentration in petiole sap and dry petiole tissue of tomato. the water requirements of drip-irrigated fresh market tomatoes. Using this method, we effectively predicted crop water requirements for nonmulched, bush (nontrellised) tomatoes in the mild coastal environment of Orange County as well as the hot summer environment of the San Joaquin Valley. The combination of using direct soil moisture monitoring to schedule early season drip irrigation and the CIMIS ETo percent crop canopy coverage method to determine drip irrigation volume from midseason to harvest may be the most water-efficient irrigation schedule for fresh market tomato crops. Canopy coverage estimates can be used for the entire season, but are least accurate during the early season when substantial water loss can occur from any open, wet soil surfaces.

Our nitrogen fertigation study on drip-irrigated tomatoes confirmed the results of previous field trials in California: Nitrogen applications in excess of $200 \mathrm{lb} / \mathrm{ac}$ are seldom required, except perhaps for trellised tomatoes harvested over an extended season. Similarly, Claude Phene, USDA-ARS, has found that processing tomatoes respond to somewhat high $\mathrm{N}$ rates in field conditions conducive to very high yields. A tomato crop's nitrogen requirements are modest in comparison with most other vegetable crops, due to its extensive root system and its ability to efficiently extract nitrogen from soil.

A new on-farm technique for monitoring crop $\mathrm{NO}_{3}-\mathrm{N}$ status that we tested as a separate part of the fertigation study may be useful in more efficiently scheduling nitrogen fertigation of fresh market tomatoes. The technique involves analyzing petiole sap with a nitrate-selective electrode and will be relatively easy to implement in commercial tomato production.

T. K. Hartz is Extension Specialist, Department of Vegetable Crops, UC Davis; M. LeStrange is Farm Advisor, Tulare County; D. M. May is Farm Advisor, Fresno County.

This work was partially supported by California Department of Food and Agriculture Fertilizer Research and Education Program. 